\title{
KARAKTERISTIK HUBUNGAN BALOK-KOLOM PADA STRUKTUR BALOK TINGGI DENGAN PENGEKANGAN
}

\section{Characteristics ofBeam - Column Connectian on Deep beam Constructian with Confinement}

\author{
Ninik Catur EY ${ }^{1} \&$ Agus Subiyanto ${ }^{2}$
}

\author{
1,2Jurusan Teknik Sipil Universitas Merdeka Malang \\ Alamat korespondensi : Jl. Terusan Raya Dieng No. 62-64 Telp. (0341) 567617 Fax. (0341)567617 \\ Email : nien_cey@yahoo.com
}

\begin{abstract}
The main problem which is the basis of this research is the frequent occurrence of collapse in the construction of deep beam and deep beam-column connection. This collapse affected by retrofitting reinforcement models. The use of less reinforcement and construction of behavior change can lead to failure due to the imposition of the construction. Tests carried out on beam-column connections with variations without restraints and restraint areas pedestal and press the path of the beam. Based on the analysis and data processing, it is known that the model of restraint with spasing $65 \mathrm{~mm}$ and $32.5 \mathrm{~mm}$ made to beam does not significantly affect the increase in the capacity of a flexible but highly influential on shear strength and ductility (indicated by a moment of curvature) and beam connection column. This condition applies both to restraints imposed in the staging area, and curbs on the press beam path. The most obvious influence is shown in spasing restraint with a distance of $32.5 \mathrm{~mm}$ mounted on the path of the beam press. Improved performance connection beams and columns are also shown on the deflection at the same load intensity, deflection occurs is smaller compared to the ones without restraint. Steel strain that occurs also decreased so that at peak load and load initial crack strain melting occurs at the load value P is greater. Based on the observation of the pattern of crack propagation, the beams were wearing restraints, pattern collapse is the kind of collapse that happened so the pliable nature of the collapse is happening is more ductile
\end{abstract}

Keywords : fly ash, permeability, absorption

\begin{abstract}
Abstrak
Permasalahan utama yang menjadi dasar penelitian ini adalah sering terjadinya keruntuhan pada konstruksi balok tinggi dan hubungan balok tinggi-kolom. Keruntuhan ini dipengaruhi oleh model perkuatan tulangannya. Pemakaian tulangan yang kurang dan perubahan perilaku konstruksi akibat pembebanan dapat mengakibatkan kegagalan konstruksi. Pengujian dilakukan terhadap sambungan balok-kolom dengan variasi tanpa pengekangan dan pengekangan di daerah tumpuan dan jalur tekan balok. Berdasarkan hasil analisis dan pengolahan data, diketahui bahwa model pengekangan dengan spasing $65 \mathrm{~mm}$ dan 32,5 mm yang dilakukan terhadap balok tidak berpengaruh secara signifikan terhadap peningkatan kapasitas lentur namun sangat berpengaruh terhadap kuat geser dan daktilitas (yang ditunjukkan oleh momen kurvatur) sambungan balok dan kolom. Kondisi ini berlaku baik untuk pengekangan yang dilakukan di daerah tumpuan, maupun pengekangan pada bagian jalur tekan balok. Pengaruh paling nyata ditunjukkan pada spasing pengekangan dengan jarak 32,5 mm yang dipasang pada jalur tekan balok. Peningkatan kinerja sambungan balok dan kolom juga ditunjukkan dari defleksi pada intensitas beban yang sama, defleksi yang terjadi lebih kecil jika dibandingkan dengan yang tanpa pengekang. Regangan baja yang terjadi juga mengalami penurunan sehingga pada beban puncak dan beban retak awal regangan leleh terjadi pada nilai beban $\mathrm{P}$ yang lebih besar. Berdasarkan pengamatan terhadap pola rambatan retak, pada balok yang memakai pengekang, pola keruntuhan yang terjadi adalah jenis keruntuhan lentur sehingga sifat keruntuhan yang terjadi lebih bersifat daktail.
\end{abstract}

Kata Kunci : hubungan balok tinggi-kolom, pengekangan, perilaku 


\section{PENDAHULUAN}

Upaya untuk memperbaiki kelemahan balok tinggi ini sudah banyak dilakukan. Penelitian untuk memperbaiki kelemahan balok tinggi yang pernah dilakukan antara lain dengan cara memberikan tulangan geser longitudinal pada bagian badan balok, memberikan sistem perkuatan dari luar balok yang disebut "clamping stirrup externally" (Robin dkk, 2010), ataupun memasang tulangan lateral khusus selain sengkang sebagai tulangan pemikul gesernya. Metode ini selanjutnya lebih dikenal dengan konsep pengekangan (confinement).

Perkuatan balok tinggi dengan pengekangan pada tumpuan dan jalur tekan balok juga memberikan hasil terjadinya peningkatan kapasitas beban retakgeser, beban ultimitbaloktinggi, kekakuangeser dan kuatgeserbaloktinggi serta dapat meningkatkan daktilitas struktur balok tinggi (Ninik, 2008). Hasil dari berbagai penelitian tersebut terbukti dapat memperbaiki perilaku dan meningkatkan kapasitas balok tinggi untuk menerima beban dan mereduksi lebar retak yang terjadi.

Kolom sebagai salah satu bagian struktur rangka yang, harus memiliki kekuatan, stabilitas dan daktilitas di dalam meneruskan beban dari balok dan diteruskan ke tanah melalui pondasi. Sambungan balok dan kolom merupakan bagian yang penting dan menjadi penopang utama konstruksi gedung secara keseluruhan dalam menjamin keamanan konstruksi. Oleh karena itu sambungan balok dan kolom harus memiliki perilaku yang ductile dengan berpegang pada konsep strong coloumn weak beam. Penelitian ini menjadi sangat penting untuk dilakukan sebagai kelanjutan penelitian yang dilakukan sebelumnya dengan pengamatan pada pola keruntuhan dan daktilitasnya. Pada penelitian ini akan dilihat apakah model perkuatan balok tinggi dengan pengekangan pada tumpuan dan jalur tekan balok akan mempengaruhi perilaku dan kinerja sambungan balok tinggi dan kolom sebagai bagian dari konstruksi portal beton bertulang.

\section{METODE PENELITIAN}

\section{Rancangan Penelitian}

Penelitian diawali pada pengujian sambungan balok tinggi dan kolom (joint balok-kolom) tanpa
pengekang.Penulangan lentur dipakai $4 \phi 10 \mathrm{~mm}$ pada sisi tarik dan $210 \mathrm{~mm}$ pada sisi tekan, sengkang $610 \mathrm{~mm}$. Mutu beton yang digunakan fc' $=25 \mathrm{MPa}$, sedangkan ukuran penampang balok $(15 \times 40) \mathrm{cm}$ dan kolom (30x30) cm yang direncanakan dengan konsep balok lemah kolom kuat.

Berikutnya dilakukan pengujian dan pengamatan pada sambungan balok tinggi dan kolom (joint balok-kolom) dengan spesifikasi yang sama tetapi pengekang diberikan pada daerah jalur tekan atau tumpuan balok. Spasing diberikan dengan variasi $35 \mathrm{~mm}$ dan $65 \mathrm{~mm}$.

Rancangan variasi benda uji dan detail benda uji seperti terlihat pada tabel. 1 dan gambar 1 berikut

Tabel 1. Jumlah Benda Uji

\begin{tabular}{|c|c|c|c|}
\hline \multicolumn{2}{|c|}{ Varian benda uji } & \multirow[b]{2}{*}{$\begin{array}{l}\text { Kode Benda } \\
\text { Uji }\end{array}$} & \multirow[b]{2}{*}{$\mathrm{Jml}$} \\
\hline $\begin{array}{l}\text { Varian-1 } \\
\text { (Lokasi) }\end{array}$ & $\begin{array}{c}\text { Varian-2 } \\
\text { (Spasing) }\end{array}$ & & \\
\hline $\begin{array}{l}\text { Kekangan } \\
\text { pada }\end{array}$ & $\begin{array}{c}\text { Spasing } 65 \\
\text { mm }\end{array}$ & JBK-KT1 & 3 \\
\hline $\begin{array}{l}\text { tumpuan } \\
\text { balok }\end{array}$ & $\begin{array}{c}\text { Spasing } 32,5 \\
\mathrm{~mm}\end{array}$ & JBK-KT2 & 3 \\
\hline \multirow{3}{*}{$\begin{array}{l}\text { Kekangan } \\
\text { pada jalur } \\
\text { tekan balok }\end{array}$} & $\begin{array}{c}\text { Spasing } 65 \\
\text { mm }\end{array}$ & JBK-KJT 1 & 3 \\
\hline & $\begin{array}{c}\text { Spasing } 32,5 \\
\mathrm{~mm}\end{array}$ & JBK-KJT 2 & 3 \\
\hline & Jumlah Benda Uji & & 12 \\
\hline
\end{tabular}

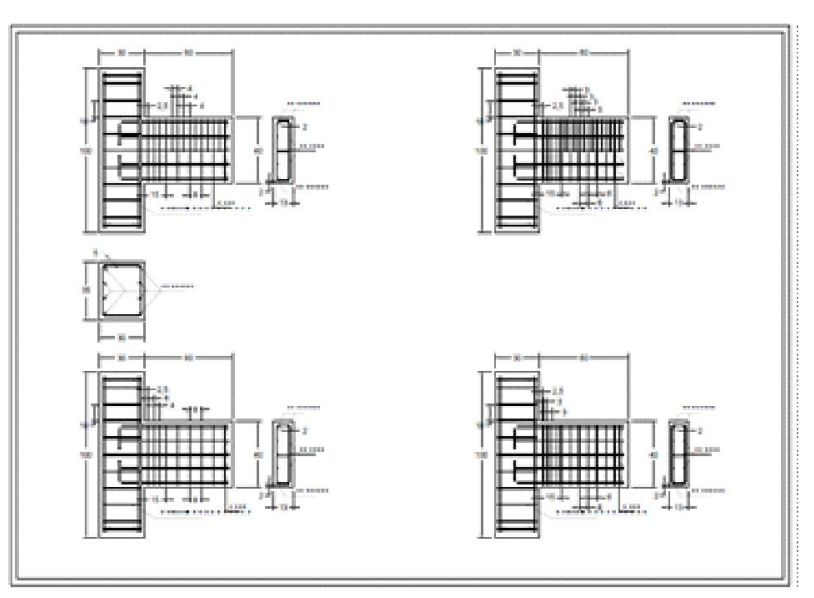

Gambar 1. Model benda uji

Pengujian hubungan balok-kolom dilakukan dengan memakai Loading Frame dengan skema pembebanan seperti terlihat pada Gambar-2. Pembacaan yang dilakukan pada pengujian tersebut adalah data beban yang diberikan setiap kenaikan $100 \mathrm{~kg}$, beban saat retak awal balok, beban saat kondisi ultimit tercapai, displacemen pada titik beban (digunakan untuk menghitung rotasi joint). 
Pengamatan yang dilakukan adalah pola retak yang terjadi mulai retak awal sampai kondisi ultimit tercapai.

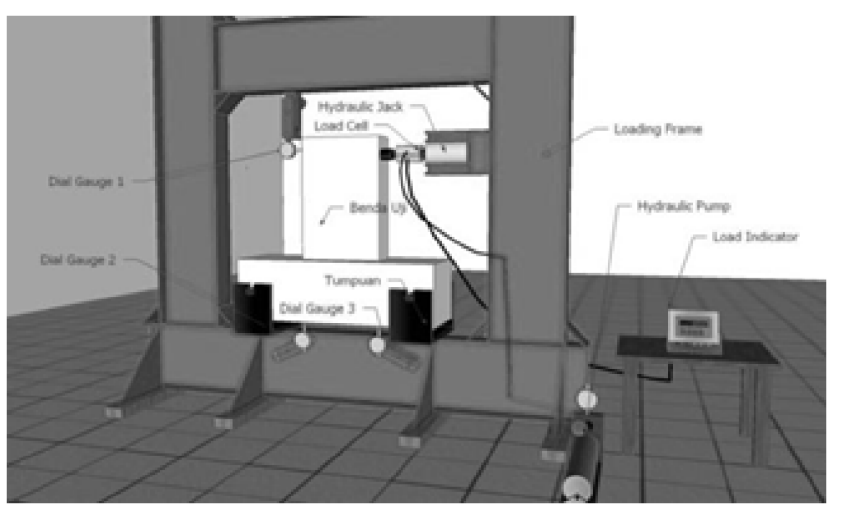

Gambar 2. Model pengujian

\section{Alat Penelitian}

Alat utama yang digunakan pada penelitian antara lain adalahcompression test machine, loading frame, proving ring, dial gauge, dan digital strain meter,

\section{HASIL DAN PEMBAHASAN}

\section{Hubungan antara Beban dan defleksi}

Hasil yang diperoleh adalah data pengujian mengenai mengenai karakteristik bahan dan hasil pengujian model sambungan balok tinggi dan kolom beton bertulang. Data mengenai uji material telah dianalisa dan telah memenuhi standar yang ditentukan SNI sebagai bahan penyusun beton

Berdasarkan hasil pengujian, diperoleh hubungan antara beban $(\mathrm{P})$ yang mampu diterima, terhadap defleksi (") yang terjadi seperti terlihat pada gambar 3. Hasil pengujian menunjukkan bahwa peningkatan kapasitas dan kekakuan balok tinggi terjadi pada model joint yang diberi pengekangan, baik kekangan pada tumpuan maupun pada jalur tekan. Hasil terbaik diberikan oleh model model joint yang terkekang pada jalur tekan dengan jarak spasing 32,5 mm. Kondisi ini dapat dijelaskan sesuai dengan hasil penelitian Singh dkk, pada tahun 2006 yang menyatakan bahwa daerah kerusakan balok tinggi berdasarkan teori lenturan berupa keruntuhan yang bersifat anchorage pada daerah tumpuan balok tinggi dapat diperbaiki dengan model perkuatan pengekang berdasarkan strut and tie.

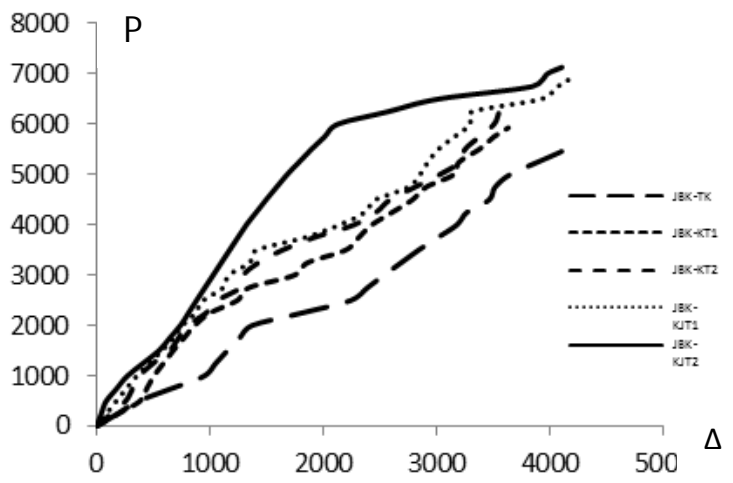

Gambar 3. Hubungan P (beban) dan “ (defleksi)

Peningkatan kapasitas beban ultimit terbesar (26\%) diberikan oleh joint balok tinggi dan kolom dengan pengekangan balok pada jalur tekan dengan spasing $32,5 \mathrm{~mm}$. Hasil ini memperkuat hasil penelitian yang dilakukan oleh Robin Tuchscherer, dkk (2010) yang menyatakan bahwa kekangan triaksial yang diberikan terhadap balok tinggi akan meningkatkan kapasitas tekan beton sehingga kemampuan untuk menerima beban juga akan semakin besar.

\section{Variasi kekangan dan kapasitas geser}

Berdasarkan hasil pengujian terlihat bahwa terjadi peningkatan kapasitas geser terhadap jointdengan berbagai variasi pengekangan balok serta balok tanpa pengekangan sebagai pembandingnya. Peningkatan kapasitas geser ini terjadi akibat pengekangan yang menyebabkan perubahan perilaku inti beton ketika menerima beban. Pengembangan inti beton menjadi terhalang sehinggameningkatkan kekuatan balok dalam menahan beban. Terlihat bahwa peningkatan kapasitas geser pada joint dengan balok terkekang pada jalur tekan memberikan peningkatan yang paling besar dalam memperbaiki perilaku keruntuhan geser yang terjadi pada joint balok tinggi dan kolom, yaitu sebesar 4,63\%.

Spasing pengekangan pada balok memberikan pengaruh nyata terhadap peningkatan kapasitas beban yang bisa diterima oleh joint balok-kolom. Gambar 4 menunjukkan bahwa spasing 32,5 mm memberikan peningkatan kapasitas yang paling baik sebesar $26 \%$ dibandingkan dengan balok tanpa kekangan. 


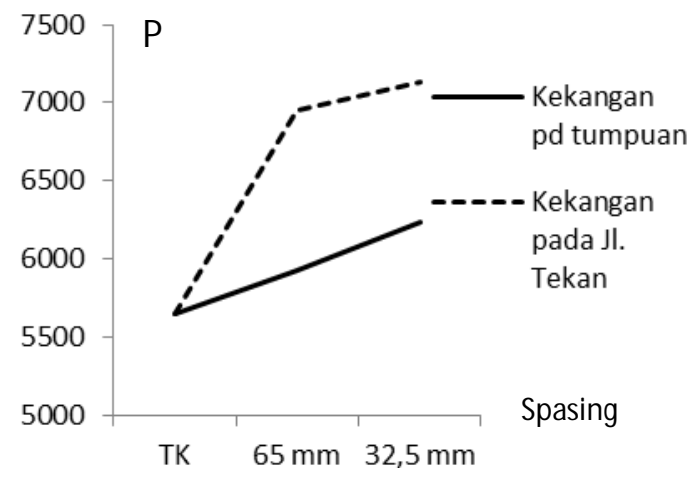

Gambar 4. Hubungan Kapasitas Beban P dengan variasi spasing

\section{Mekanisme Keruntuhan}

Berdasarkan pengamatan pada saatpengujian, mekanisme keruntuhan yang terjadi pada sambungan balok-kolom yang tanpa pengekangan balok, retak awal terjadi saat tekanan sebesar $2000 \mathrm{~kg}$ pada daerah balok, kurang lebih $11 \mathrm{~cm}$ dari joint, retak pertama dari tepi balok merambat ke tengah balok dengan cepat. Dilanjutkan dengan retakan kedua ke arah joint bersamaan dengan retak pada joint yang semakin lebar sampai terjadi keruntuhan. Mekanisme retak pada saat keruntuhan joint balok tinggi-kolom tanpa kekangan diperlihatkan pada Gambar 5.

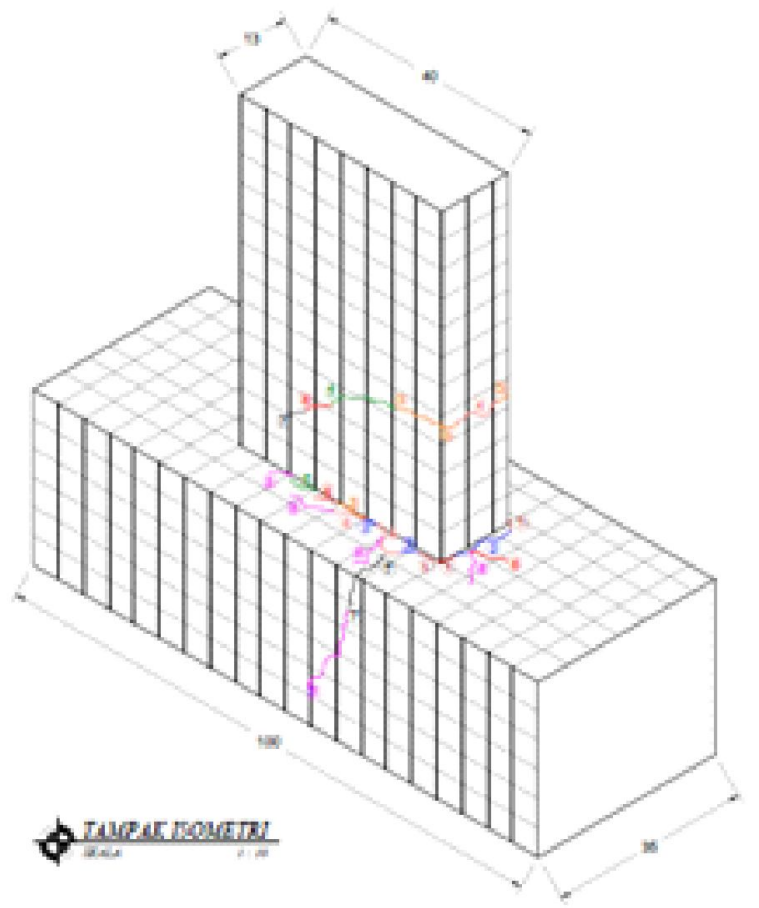

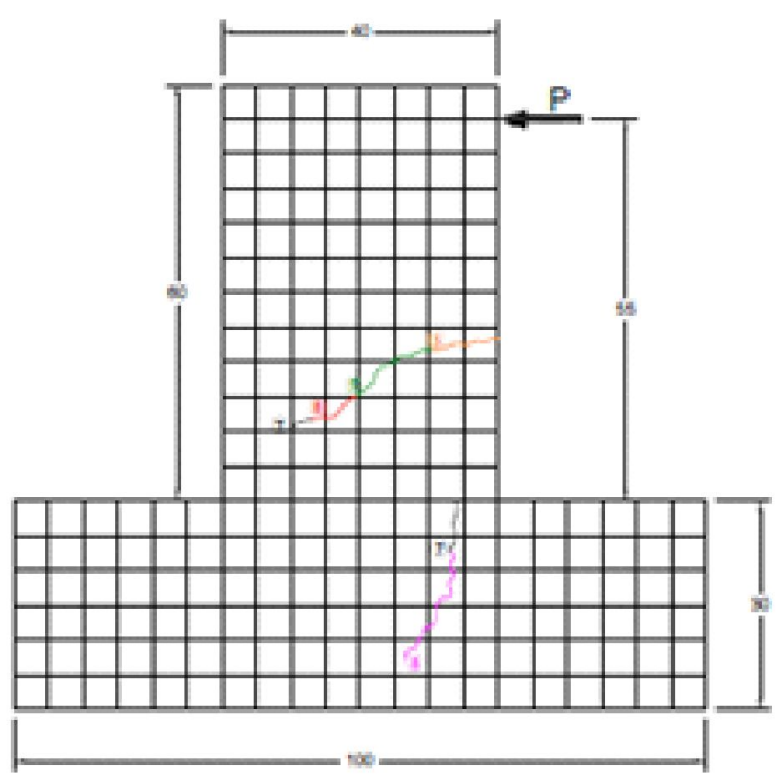

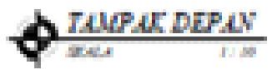

Gambar 5. Pola rambatan retak pada Sambungan balok dan kolom tanpa pengekangan

Perubahan perilaku joint akibat pengekangan pada balok ditunjukkkan pada Gambar-6 dan Gambar-7 berikut. Gambar-6 menunjukkan pola rambatan retak pada joint dengan pengekangan pada tumpuan balok. Mekanisme keruntuhan yang terjadi pada sambungan balok-kolom dengan pengekangan pada tumpuan balok diawali dengan retakyangterjadipada joint. Retakan pada joint semakin melebar dan merambat ke arah kolom seiring dengan semakin bertambahnya beban dan diikuti oleh retak baru pada daerah bentang balok. Retakpada joint dan kolom semakin lebar namun retakan pada balok hanya bertambah panjang sampai terjadi keruntuhan.

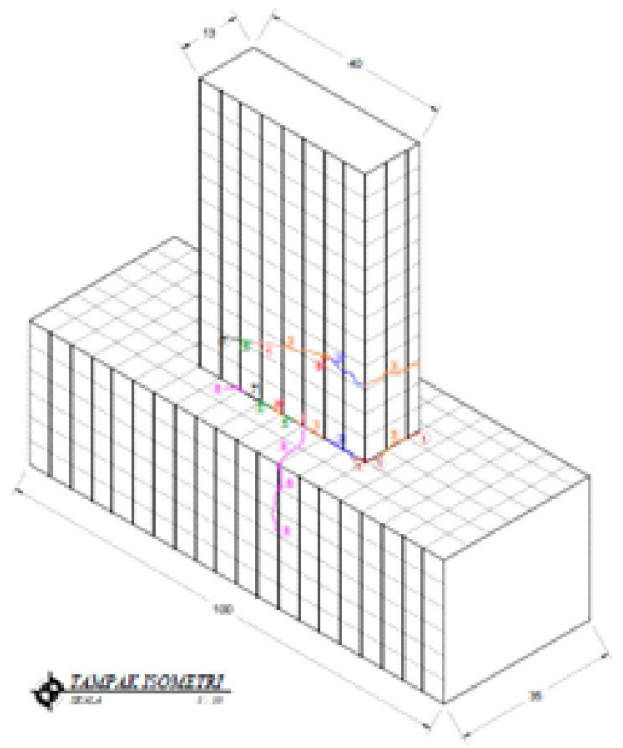




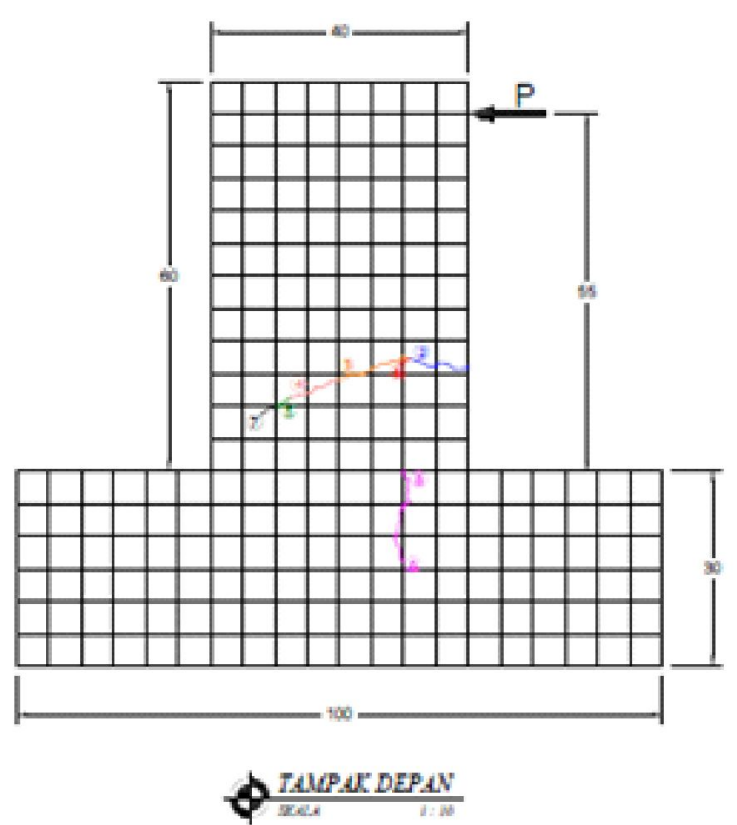

Gambar 6. Pola rambatan retak pada Sambungan balok dan kolom tanpa pengekangan

Gambar-7 menunjukkan pola rambatan retak pada joint dengan pengekangan pada jalur tekan balok. Mekanisme keruntuhan yang terjadi pada sambungan balok dan kolom dengan pengekangan pada jalur tekan balok diawali dengan retak yang terjadi pada joint. Retakan pada joint semakin melebar dan merambat ke arah kolom seiring dengan semakin bertambahnya beban dan diikuti oleh retak baru pada daerah bentang balok. Dengan bertambahnya kapasitas beban, timbul retakan baru yang mengarah ke tumpuan pada bentang balok segaris dengan titik beban. Retak pada joint dan kolom semakin lebar namun retakan pada balok hanya bertambah panjang sampai terjadi keruntuhan.

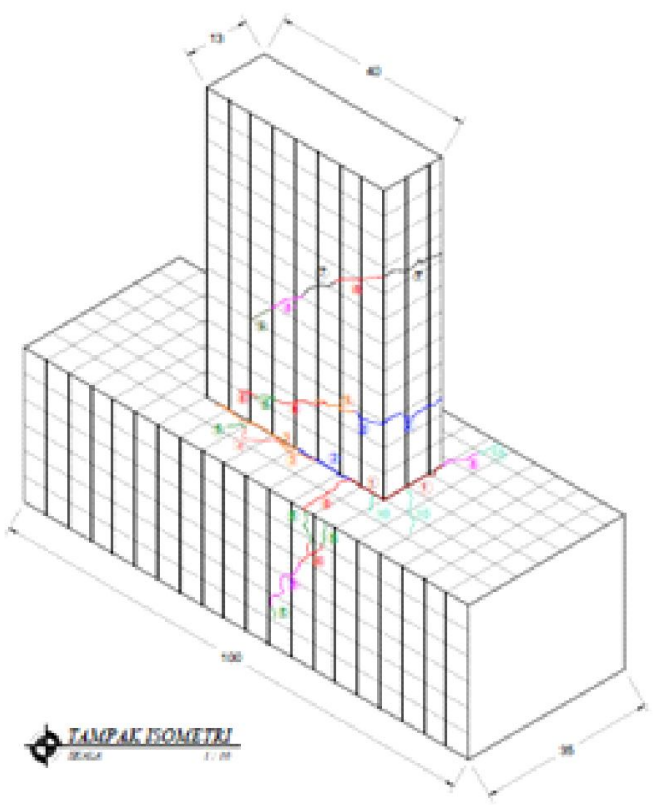

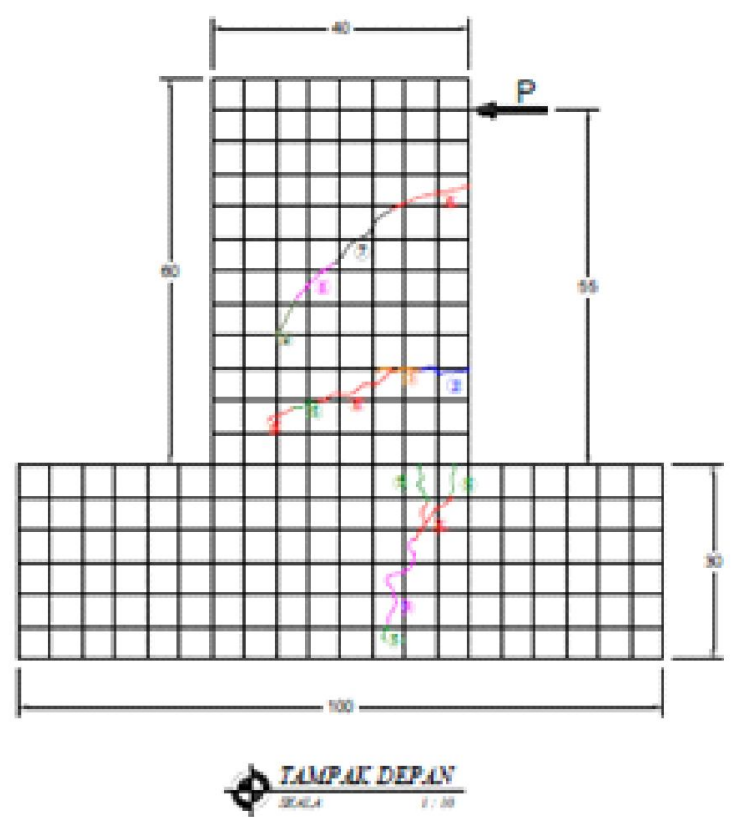

Gambar 7. Pola rambatan retak pada Sambungan balok dan kolom dengan pengekangan pada Jalur Tekan

\section{KESIMPULAN DAN SARAN}

Berdasarkan pengolahan data hasil pengujian diperoleh kesimpulan bahwa (1) pengekangan pada balok tinggi dapat meningkatkan kekakuan dan kapasitas beban ultimit yang diterima oleh joint, peningkatan kinerja sambungan balok dan kolom juga ditunjukkan dari defleksi pada intensitas beban yang sama, defleksi yang terjadi lebih kecil jika dibandingkan dengan yang tanpa pengekang ; (2) spasing dan lokasi pengekangan pada balok tinggi mempengaruhi besarnya peningkatan kapasitas beban ultimit dan kapasitas geser yang mampu diterima oleh joint; (3) peningkatan kapasitas beban ultimit terbesar (26\%) yang mampu diterima joint adalah dengan pengekangan pada jalur tekan dan jarak spasi 32,5 mm; (4) peningkatan kapasitas geser terbesar $(4,63 \%)$ yang mampu diterima joint adalah dengan pengekangan pada jalur tekan dan jarak spasi 32,5 mm; (5) pengekangan yang diberikan pada balok, baik pada bagian tumpuan maupun jalur tekan mempengaruhi model pola keruntuhan yang terjadi pada joint. Pada joint tanpa kekangan balok tinggi, keruntuhan diawali oleh retak pada balok diikuti retak pada joint sampai terjadi keruntuhan. Pada joint dengan pengekangan pada balok tinggi, keruntuhan disebabkan oleh kegagalan joint dalam menerima beban. 


\section{DAFTAR PUSTAKA}

Anonim, 1983, ACI Committee 318, Building Code Requirements for Reinforced Concrete (ACI 318-83), American Concrete Institute, Detroit, 1983, 111pp.

Anonim, 1996, ACI Code 318-95, Building Code Requirements for Structural Concrete, Portland Cement Association, Illinois, Chichago

B.R Niranjan, S.S Patil, (2012), "Shear Strength Prediction of Deep Beams by Softened Truss Model", IOSR Journal of Mechanical and Civil Engineering (IOSR-JMCE), ISSN: 2278-1684 Volume 4, Issue 1 (Nov. - Dec. 2012), PP 01-06

Dionisius, 2007, Perbaikan Perilaku MomenKurvatur Balok Beton ringan Bertulang SubstitusiAgregat Batu Apung Dengan Pengekangan Tulangan lateral pada Jalur Tekan, Laporan Penelitian Hibah Penelitian Program PHK A2 Jurusan Teknik Sipil Fakultas Teknik Unmer Malang.

Eka dan Ninik, 2006, Tinjauan Rambatan Retak dan Pola Keruntuhan Pada Balok Tinggi, Tugas Akhir Jurusan Teknik Sipil Fakultas Teknik Unmer Malang.

Kotsovos, MD; J. Bobrowski 1993, Design Model for Structural Concrete Based on the Consept of Compressive Force Path, ACI Structural Journal, Detroit, Vol. 90, No.1, pp. 12-20

Nawy E.G, 1990, Beton Bertulang Suatu Pendekatan Dasar, Eresco Bandung

Ninik, 2006, Optimalisasi Pemakaian Tulangan Geser Longitudinal Pada Struktur Balok Tinggi Beton Bertulang, Laporan Penelitian Program Hibah Kompetisi A2 Jurusan Teknik Sipil FT. Universitas Merdeka Malang.

Ninik, 2008, Rekonstruksi Penulangan Balok Tinggi dengan Pemakaian Tulangan Pengekang untuk Mencegah Keruntuhan yang Terlalu Dini, Laporan Penelitian Program Hibah Kompetisi A2 Jurusan Teknik Sipil FT. Universitas Merdeka Malang.

Park., R, Priestley M.J.N and Gill, W.D, 1982, Ductility of Square-Confined Concrete Coloumns, Journal of the Structural Division, ASCE, vol 108, p.929-950.
Robin Tuchscherer, David Birrcher, Matt Huizinga, and Oguzhan Bayrak, (2010), "Confinement of Deep Beam Nodal Regions" ACI Structural Journal, V. 107, No. 6, NovemberDecember 2010. pp. 709-717.

Sabariman, B \& Rufi'I, 2000, Analisis Pengaruh Gaya Aksial Tekan Konstan Terhadap Daktilitas Kolom Terkekang, Majalah Wahana, Edisi 39-4, Nov 2000.

Singh, B, Kaushik SK, Naveen KF, Sharma S, 2006, Design of a Continuos Deep Beam Using The Strut and Tie Method, Asian Jornal of Civil Engineering (Building and Housing), Vol. 7, No. 5, p. 461-477

Tan, K.H., C.Y Tang, and K.Tong, 2004, Shear Strength Prediction of Pierced Deep Beams with Inclined Web Reinforcement, Magazine of Concrete Research, Vol.56, Issue.8, pp.443452. 